\title{
RANCANG BANGUN APLIKASI KATALOG KERJA PRAKTEK DAN TUGAS AKHIR BERBASIS ANDROID
}

\author{
Rice Novita, Herman Zahri \\ Jurusan Sistem Informasi, fakultas sains dan teknologi, uin sultan syarif kasim riau \\ Rice.novita@uin-suska.ac.id, hermanzahri89@gmail.com
}

\begin{abstract}
Abstrak
Kerja Praktek dan Tugas Akhir merupakan karya ilmiah yang disusun oleh setiap mahasiswa yang ingin menyelesaikan jenjang pendidikan strata 1 . Dalam membuat karya ilmiah berupa laporan kerja praktek dan tugas akhir, tentunya membutuhkan banyak referensi, baik dari buku maupun penelitian penelitian yang telah dilakakan. kumpulan dari penelitian yang ada khususnya pada jurusan sistem infomasi, bisa ditemukan di perpustakaan uin fakultas dan perpustakaan uin suska riau. Hal ini menyebabkan kesulitan bagi mahasiswa dalam mendapat informasi mengenai penelitian yang telah dilakukan. Data penelitian masing masing jurusan di fakultas sains dan teknologi belum terkelompokkan dan bahkan penelitian dengan judul yang sama diajukan oleh mahasiswa, karena tidak adanya catalog mengenai penelitian yang telah dilakukan. Masalah ini dapat diselesaikan dengan merancang bangun sebuah aplikasi catalog kerja praktek dan tugas akhir berbasis android. Aplikasi ini dirancang dengan metode prencangan secara OOAD dan metode pengembangan perangkat lunak menggunakan metode prototype. memanfaatkan Smartphone android. Dengan adanya aplikasi ini, mahasiswa dapat melihat penelitian penelitian yang telah dilakukan oleh mahasiswa yang telah tamat. Informasi yang didapat berupa judul dan abstrak dari penelitian dan juga membangun web server untuk mengelola aplikasi catalog tersebut.
\end{abstract}

Kata kunci : Aplikasi, Android, Web Server

\section{A. PENDAhuluan}

Jenjang pendidik perguruan tinggi merupakan tahapan lanjutan dari pemilihan karir di bangku SMA, Pendidikan tinggi merupakan pusat pengetahuan menciptakan, memberikan, dan belajar bagi masyarakat(DHAMDHERE 2015). Membuat prediksi untuk masa depan, memecahkan masalah dengan pengetahuan pengetahuan yang ada (Tipawan Silwattananusarn and KulthidaTuamsuk 2012). Dalam hal ini Holland (Holland 1985) mengelompokkan tiga golongan untuk siswa yang telah lulus dari SMA. Diantaranya yang pertama melanjutkan pendidikan keperguruan tinggi, yang kedua minat karir ( bekerja di perusahaan atau instansi) dan yang ketiga dalah berwiraswata ( membangun usaha sendiri secara mandiri). Bagi siswa yang melanjutkan ke perguruan tinggi, akan melalui banyak proses dalam penyelesaian pendidikannya. Salah satunya melakukan kerja praktek dan tugas akhir sampai selesai, sehingga membawa gelar dan ijazah serta mendapatkan sebuah pekerjaan untuk masa depan.

Dalam proses penyelesaian kerja praktek dan tugas akhir, banyak mahasiswa merasa kesulitan dalam menyelesaikannya, kesulitan dalam mengangkat masalah, metode dan judul. Salah satunya disebabkan kurangnya informasi mengenai referensi penelitian yang telah dilakukan. Pencarian informasi penelitian yang pernah dilakukan oleh masiswa terdahulu dapat dilihat diperpustakaan. Namun belum adanya khusus untuk penelita KP dan TA. Oleh karena itu tentunya mahasiswa membutuhkan sebuah referensi judul dari penelitian terdahulu yang ada di masing masing jurusan sebagai acuan untuk meneliti selanjutnya. Permasalahan yang lain, adanya judul penelitan KP dan TA yang sama dan belum adanya pengelompokkan penelitian. katalog sangat dibutuhkan dalam proses pencarian (Estukara 2013). E-katalog berbasis android sudah banyak digunakan baik dalam penjualan hijab (Juang 2015) maupun pendidikan. Dalam pendidikan membangun aplikasi e-learning berbasis android (Parno, Matilda khaterine et al. 2014), membangun aplikasi panduan sholat, bisa digunakan untuk siapa saja dan dimanapun ingin belajar (Parno, Dharmayanti et al. 2013).

Dengan dibangunkan sebuah catalog KP dan TA berbasis android, maka mahasiswa akan mudah dalam mencari informasi dalam mengembangkan peneltian dan mengangkat masalah, solusi dan judul. Mahasiswa dapat 
mengetahui penelitan yang sudah pernah dilakukan oleh mahasiswa terdahulu, sehingga tidak ada lagi pembuatan penelitian dengan judul yang sama.

\section{A.1 Pengertian Katalog}

Secara umum pengertian katalog didefenisikan sebagai daftar barang atau benda yang disusun untuk tujuan tertentu, seperti katalog pameran, katalog perdagangan, katalog perpustakaan, dan lain-lain. Sedangkan dalam arti khusunya katalog adalah merupakan daftar dokumen (bahan pustaka) yang dimiliki oleh suatu perpustakaan yang disusun secara alfabetis menurut golongan ilmu atau menurut abjad. Katalong perpustakaan adalah daftar buku dalam sebuah perpustakaan atau dalam sebuah koleksi (Sulistyo-Basuki 1991). Proses dari pembuatan katalog itu sendiri disebut dengan istilah katalogisasi atau pengatalogan. Katalogisaasi atau pengatalogan adalah proses (pekerjaan) mengklasifikasi buku serta bahan pustaka lainnya dan membuat entri-entri yang sesuai untuk katalog perpustakaan.

\section{A.2 Android}

Android adalah sistem operasi untuk telepon seluler yang berbasis Linux. Android menyediakan platform terbuka bagi para pengembang untuk menciptakan aplikasi mereka sendiri untuk digunakan oleh bermacam peranti bergerak. Awalnya, Google Inc. membeli Android Inc., pendatang baru yang membuat peranti lunak untuk ponsel. Kemudian untuk mengembangkan Android, dibentuklah Open Handset Alliance, konsorsium dari 34 perusahaan peranti keras, peranti lunak, dan telekomunikasi, termasuk Google, HTC, Intel, Motorola, Qualcomm, T-Mobile, dan Nvidia (Nazaruddin, Safaat et al. 2012)

\section{A.3 Fitur dan Arsitektur Android}

Fitur yang tersedia pada android adalah (Hermawan and S. 2011)

1. Framework aplikasi: memungkinkan penggunaan dan pemindahan dari komponen yang tersedia.

2. Dalvik Virtual Machine: virtual machine yang dioptimalkan untuk perangkat mobile.

3. Grafik: grafik 2D dan grafik 3D yang didasarkan pada library OpenGL.

4. SQLite: untuk menyimpan data.

5. Mendukung media: audio, video, dan berbagai format gambar (MPEG4,
H.264, MP3, AAC, AMR, JPG, PNG, GIF).

6. GSM, Bluetooth, EDGE, 3G, and WiFi (tergantung hardware)

7. Camera, Global Positioning System (GPS), compass, dan accelerometer (tergantung hardware)

8. Lingkungan pengembangan yang kaya, termasuk emulator, peralatan dabugging, dan plugin untuk IDE Eclipse.

Sistem operasi android dibangun berdasarkan kernel Linux yang memiliki arsitektur seperti gambar berikut.(Nazaruddin, Safaat et al. 2012)

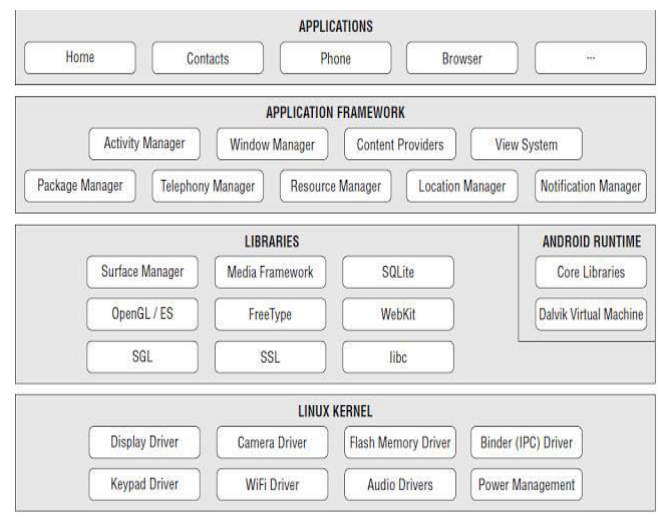

Gambar 1. Arsitektur Android

Pada gambar 1 menjelaskan arsitektur android, dari application sampai linux kerner.

\section{A.4 Pendekatan Berorientasi Objek}

Pendekatan berorientasi objek merupakan paradigma pemrograman yang berorientasikan kepada objek. Semua data dan fungsi di dalam paradigma ini dibungkus dalam kelas-kelas atau objek-objek. Pada Objek Oriented terdapat beberapa model pendekatan,yaitu Object Oriented Programming (OOP) dan Object Oriented Analysis and Design (OOAD). Object Oriented Programming (OOP) atau Pemrograman Berorientasi Objek adalah konsep pemrograman yang difokuskan pada penciptaan kelas yang merupakan abstraksi/blueprint/prototype dari suatu objek. Kelas ini harus mengandung sifat (data) dan tingkah laku (method) umum yang dimiliki oleh objek-objek yang kelak akan dibuat (diinstansiasi). Data dan method merupakan anggota dari suatu kelas. Sedangkan Object Oriented Analysis and Design (OOAD) 
adalah metode analisis yang memeriksa requirements dari sudut pandang kelas dan objek yang ditemui dalam ruang lingkup permasalahan yang mengarahkan arsitektur software yang didasarkan pada manipulasi objek-objek sistem atau subsistem. OOAD merupakan cara baru dalam memikirkan suatu masalah dengan menggunakan model yang dibuat menurut konsep sekitar dunia nyata. Dasar pembuatan adalah objek, yang merupakan kombinasi antara struktur data dan perilaku dalam satu entitas. Dari beberapa model Object Oriented diatas, maka dalam peneletian ini, saya akan menggunakan model Object Oriented Analysis and Design (OOAD). Perancangan sistem informasi dengan metode ooad dapat membantu dalam membangun sebuah aplikasi.tidak hanya catalog magang dan tugas akhir. Dalam hal pemetaan juga dapat digunakan (Rice Novita and Karluci 2015)

\section{B. METODE}

Dalam Membuat aplikasi ini, metode penelitian yang dilakukan dengan analisa kebutuhan user, analisa kebutuhan sistem, pengkodingan dan implementasi. Sedangkan data dan informasi yang didapat berdasarkan data dari masing masing jurusan. Selanjutnya penulis menganalisis data yang telah dikumpulkan untuk membuat aplikasi ini secara bertahap:

a. Analisa dan Perancangan system dengan menggunakan UML.

b. Perancangan tampilan dari aplikasi tersebut (interface).

c. Pengkodingan

d. Kemudian melakukan uji coba aplikasi yang didahului dengan proses debugging, program yang sudah valid dan terverifikasi selanjutnya dijalankan.

e. Pengimplementasian aplikasi pada emulator Android dan Perangakat Genggam dengan Sistem Operasi Android.

\section{ANALISA DAN HASIL}

\section{C.1 Deskripsi Umum Sistem}

Katalog Kerja Praktek dan Tugas Akhir
yang dibangun merupakan aplikasi mobile
menggunakan konsep client server yang terkoneksi
dengan jaringan internet. Aplikasi ini berfungsi untuk
mempermudah mahasiswa dalam pencarian informasi
judul KP dan TA yang ada pada jurusan Sistem
Informasi yang memberikan informasi nama peneliti,
judul penelitian, abstrak penelitian, pembimbing,

penguji, metode penelitian dan lokasi penelitian dari masing-masing judul.

Selain itu katalog KP dan TA juga mengunakan sistem berbasis web yang berfungsi sebagai pengelola data katalog yang dikelolah oleh admin dan koordinator KP dan koordinator TA. Adapun bertugas dari admin, koordinator KP dan TA untuk mengelolah informasi nama peneliti, judul penelitian, abstrak penelitian, pembimbing, penguji, metode penelitian dan lokasi penelitian dari masingmasing judul dengan menginputkan data tersebut pada web server kemudian data disimpan pada database MySQL. Data yang dikelola petugas melalui web server akan muncul pada aplikasi mobile berbasis android dengan cara terkoneksi oleh jaringan internet untuk menghubungkan aplikasi dengan web server melalui database MySQL.

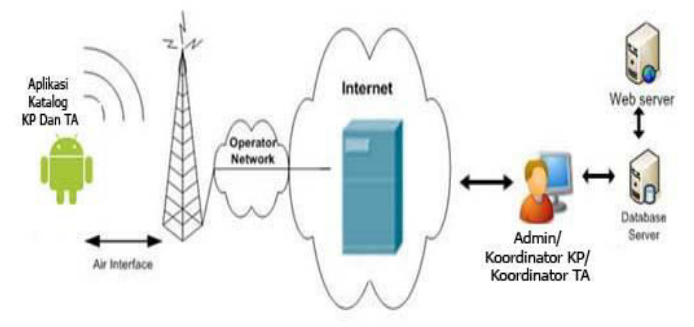

Gambar 2. Deskripsi umum Aplikasi KP dan TA

Pada Gambar 2 menjelaskan secara umum aplikasi catalog KP dan TA

\section{C.2 Proses Pembuatan Aplikasi}

Proses pembuatan aplikasi di mulai dari tahap pengumpulan data dengan melakukan pengamatan dan wawancara terhadap beberapa mahasiswa jurusan Sistem Informasi yang akan melakukan penelitian dengan menanyakan permasalahan apa yang dihadapi saat menentukan judul penelitian dan apa yang sangat dibutuhkan saat menentukan judul penelitian tersebut. Dari pertanyaan ini dapat disimpulkan bahwa mereka membutuhkan sebuah referensi judul berupa katalog. Maka dari itu dibuatlah sebuah aplikasi katalog KP dan TA yang dapat memudahkan mahasiswa menemukan referensi judul penelitian mereka. Adapun proses pembuatan aplikasi katalog kerja peraktek dan tugas akhir dapat dilihat dalam alur berikut ini : 


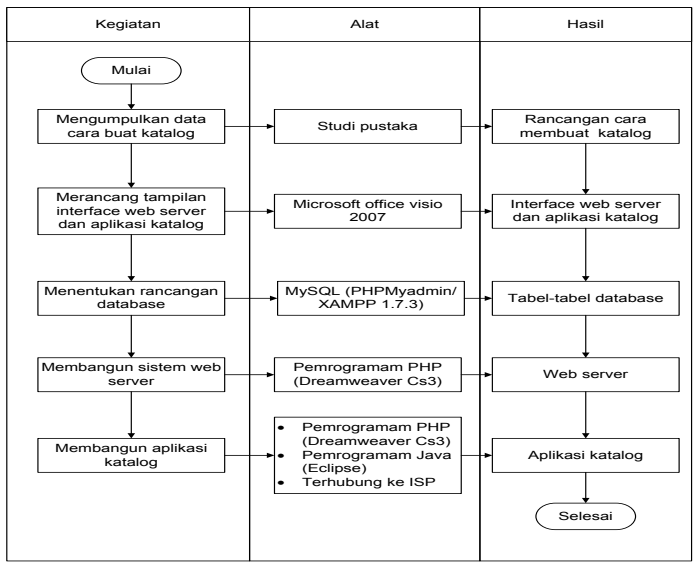

Gambar 3. Alur Pembuatan Aplikasi

Pada gambar 3 merupakan alur pembuatan aplikasi catalog KP dan TA pada fakultas sains dan teknologi yang dimulai dari start dan end.

\section{C.3 Perancangan Sistem}

\section{Use Case Diagram}

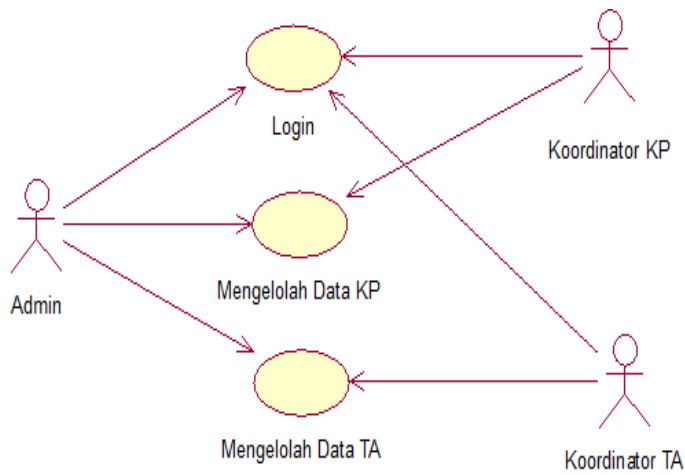

Gambar 4 Use Case Diagram Admin pada Web

Server

Pada gambar 4 menggambarkan use case diagram admin, mempunyai tiga use case dan terdapat tiga actor.

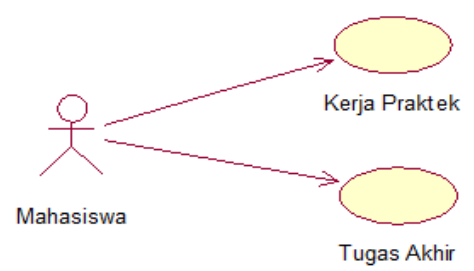

Gambar 5 Use Case Diagram Mahasiswa pada aplikasi katalog
Pada gambar 5 menggambarkan use case diagram untuk actor mahasiswa, mempunyai dua use case dengan actor mahasiswa.

\section{Activity Diagram}

Activity Diagram menggambarkan berbagai alir aktivitas dalam sistem yang sedang dirancang, bagaimana masing-masing alir berawal, decision yang mungkin terjadi, dan bagaimana mereka berakhir. Activity diagram yang di jelaskan pada gambar di bawah ini ialah menggambarkan aktivitas pada web server maupun pada aplikasi android katalog.

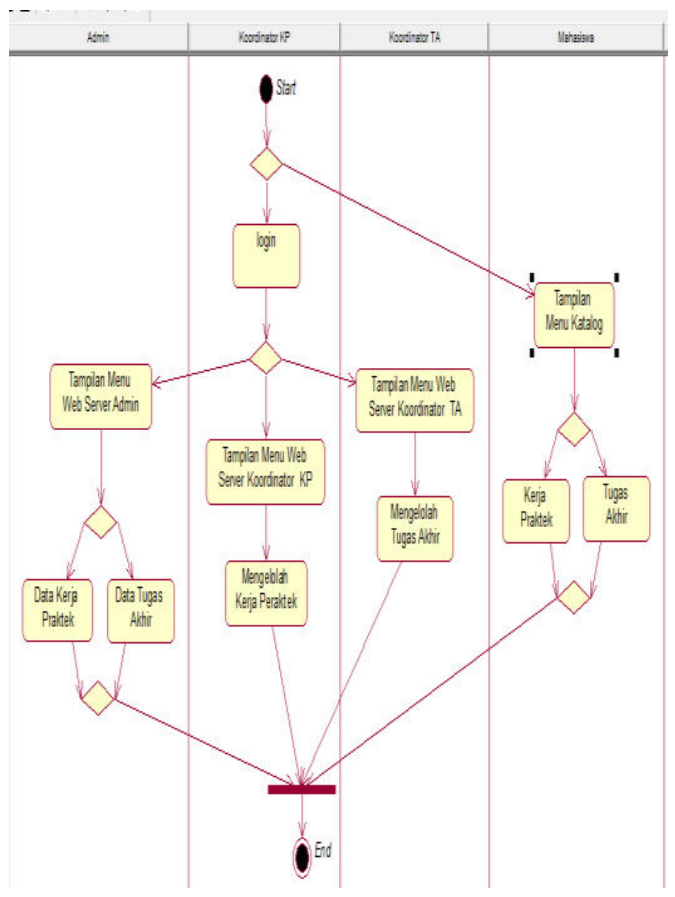

Gambar 6 Activity Diagram

Pada gambar 6 menggambarkan alir aktifitas sistem catalog dibangun dan digunakan.

\section{Class Diagram}

Class Diagram menggambarkan struktur dan deskripsi class, package, dan objek yang saling terhubung. Class diagram yang dijelaskan pada analisa ini adalah class diagram sistem yang terpasang pada web server dan prangkat android. 
Jurnal Ilmiah Rekayasa dan Manajemen Sistem Informasi, Vol. 4, No. 2, Agustus 2018, Hal. 209-215

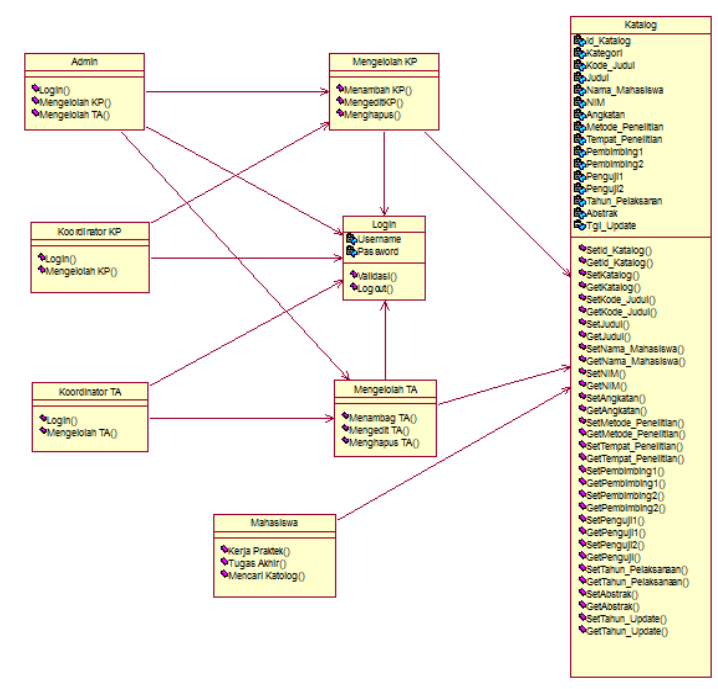

Gambar 7 Class Diagram Web Server dan Aplikasi Katalog

Pada gambar 7 memperlihatkan relasi antar class pada sistem kalatog yang dibangun.

\section{C.4 Aplikasi Katalog}

Halaman Menu Utama Aplikasi Katalog

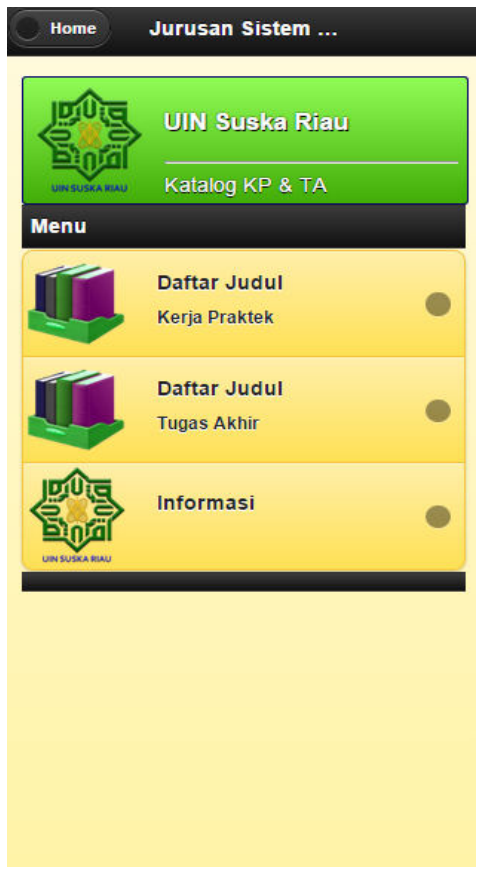

Gambar 8 Halaman Menu Utama Aplikasi Katalog Pada gambar 8 adalah halaman menu pada catalog judul kerja praktek dantugas akhir.

\section{Halaman Daftar Judul Kerja Praktek}

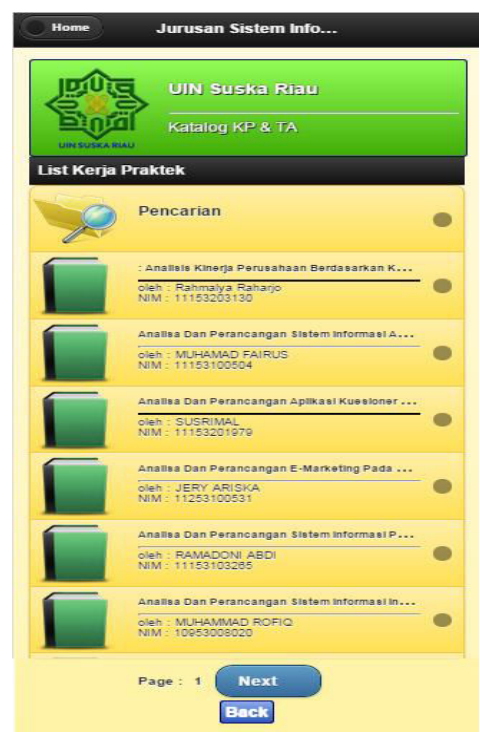

Gambar 9. Halaman Daftar Judul Kerja Praktek

Pada gambar 9 adalah halaman daftar judul kerja praktek yang dapat diakses oleh mahasiswa pada aplikasi catalog judul kerja praktek dantugas akhir.

Halaman Informasi Salah Satu Judul Tugas Akhir

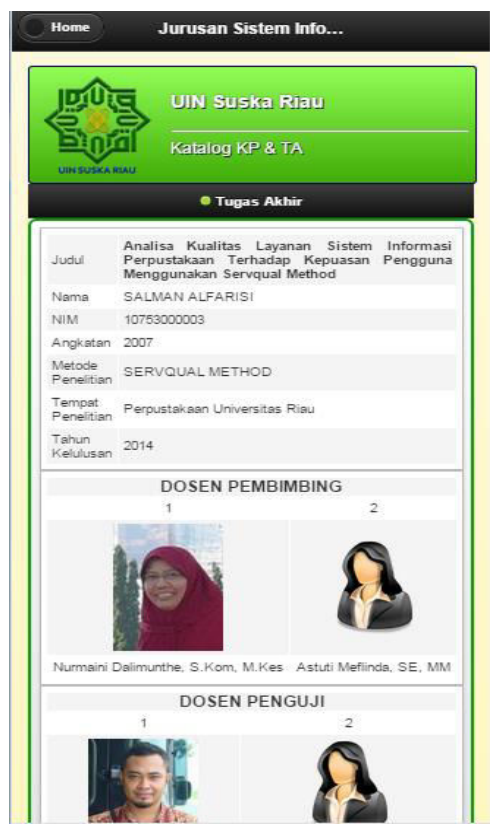

Gambar 10. Halaman Informasi Salah Satu Judul Tugas Akhir 
Pada gambar 10 adalah halaman informasi salah satu judul akhir yang dapat diakses oleh mahasiswa pada aplikasi catalog judul kerja praktek dantugas akhir.

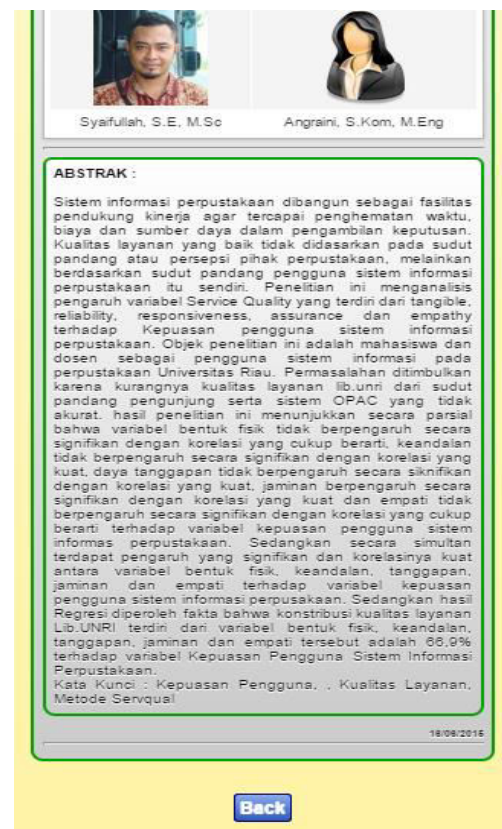

Gambar 11 Halaman Informasi Salah Satu Judul Tugas Akhir (Lanjutan)

Pada gambar 11 adalah halaman informasi yang dapat diakses oleh mahasiswa pada aplikasi catalog judul kerja praktek dantugas akhir.

\section{PENUTUP}

Dari penelitian dan pembuatan aplikasi katalog kerja praktek dan tugas akhir berbasis android untuk mahasiswa fakultas sains dan teknologi yang akan melaksanakan penelitian dapat ditarik kesimpulan yaitu:

1. Aplikasi katalog memberikan layanan informasi kumpulan judul Kerja Praktek dan judul Tugas Akhir kepada mahasiswa Fakultas Sains dan Teknologi UIN Suska Riau.

2. Aplikasi katalog memudahkan mahasiswa untuk memperoleh referensi dan gambaran judul Kerja Praktk dan Tugas Akhir dari katalog Kerja Praktk dan Tugas Akhir berbasis android

3. Dengan adanya aplikasi katalog kerja praktek dan tugas akhir, mahasiswa dan dosen dapat mengetahui informasi judul Kerja Praktek dan Judul Tugas Akhir apa saja yang telah ada dan dibuat sebelumnya oleh mahasiswa fakultas sains dan teknologi.
4. Pengujian aplikasi menggunakan beberapa perangkat android dan web server dan menunjukkan semua fitur aplikasi dapat berjalan dengan baik secara online.

Dalam pembangunan aplikasi katalog kerja praktek dan tugas akhir berbasis android ini masih terdapat beberapa kekurangan. Oleh karena itu perlu dilakukan pengembangan dan penyempurnaan lebih lanjut. Adapun saran agar aplikasi katalog ini bisa berfungsi dengan lebih optimal dan lebih menarik dan Penggunaan aplikasi ini hanya bisa digunakan pada satu Platform yaitu Mobile dengan Sistem Operasi Android, kedepan harapannya jika ingin dikembangkan bisa digunakan Multiplatform.

\section{E. DAFTAR PUSTAKA}

[1]. Dhamdhere, s. N. (2015). "importance of knowledge management in the higher educational institutes."

[2]. Estukara, p. (2013). Perancangan dan pembuatan e-katalog berbasis android pada tee company yogyakarta

[3]. Sekolah tinggi manajemen informatika dan komputer amikom yogyakarta

[4].Hermawan and s. S. ( 2011). Mudah membuat aplikasi android yogyakarta andi offset.

[5]. Holland, j. L. (1985). "making vocational choice: a theory of vocational personalities and work environments (2nd edition). New jersey: prentice-hall. Inc.".

[6].Juang, a. (2015). "rancang bagun aplikasi mobile ekatalog berbasis ios sebagai media bantu pengenalan produk miulan ".

[7]. Nazaruddin, safaat, et al. (2012). Pemrograman aplikasi mobile smartphone dan tablet pc berbasis android. Bandung informatika.

[8].Parno, dharmayanti, et al. (2013). "rancang bangun aplikasi e-learning tuntunan sholat lengkap berbasis mobile android

[9]." seminar nasional teknologi informasi dan komunikasi.

[10]. Parno, matilda khaterine, et al. (2014). "rancang bangun aplikasi e-learning bangun ruang tiga dimensi bernasis mobile android." 5 no. 1 .

[11]. Rice novita and karluci (2015). "sistem informasi pemetaan daerah terjangkit demam berdarah dengue (dbd) wilayah kota pekanbaru (studi kasus : dinas kesehatan kota pekanbaru)." 
Jurnal Ilmiah Rekayasa dan Manajemen Sistem Informasi, Vol. 4, No. 2, Agustus 2018, Hal. 209-215

e-ISSN 2502-8995, p-ISSN 2460-8181

rekayasa dan management sistem informasi 1 no 1.

[12]. Sulistyo-basuki (1991). Pengantar ilmu perpustakaan. Jakarta: gramedia pustaka utama.

[13]. Tipawan silwattananusarn and p. D. Kulthidatuamsuk (2012). "data mining and its applications for knowledge management : a literature review from 2007 to 2012." 